\title{
First National-Scale Evaluation of Temephos Resistance in Aedes Aegypti in Peru.
}

\author{
Miriam Palomino ( $\sim$ mpalominosal@gmail.com ) \\ Fundação Oswaldo Cruz: Fundacao Oswaldo Cruz \\ Jesus Pinto \\ Instituto Nacional de Salud
}

\section{Pamela Yañez}

Instituto Nacional de Salud

\section{Anali Cornelio \\ Instituto Nacional de Salud \\ Luciana Dias \\ Fundacao Oswaldo Cruz \\ Quesia Amorim}

Fundacao Oswaldo Cruz

\section{Audrey Lenhart}

Centers for Disease Control and Prevention

Jose Bento Pereira Lima

Fundacao Oswaldo Cruz

\section{Research Article}

Keywords: Aedes aegypti, arboviruses, insecticide resistance, temephos, Resistance Ratio (RR), vector control.

Posted Date: February 7th, 2022

DOI: https://doi.org/10.21203/rs.3.rs-1254899/v1

License: (c) (i) This work is licensed under a Creative Commons Attribution 4.0 International License. Read Full License 


\section{Abstract}

Background: Resistance of Aedes aegypti to insecticides can lead to operational failures in control programs. Knowledge of the spatial and temporal trends of this resistance is needed for effective monitoring, on which vector control decisionmaking should be based.

Methods: The organophosphate insecticide temephos was evaluated in L3 larvae in dose-response bioassays with eleven concentrations of the insecticide, following WHO recommendations. The mosquitoes tested were Ae. aegypti larvae of F1 and F2 generations from eggs collected with ovitraps during 2018 and 2019.

Results: The results segregated into two geographic groups. The first group, from the coast, was mostly resistant to temephos (RR > 10), with three populations ( $A G, C R$ and LO) showing RR values greater than 20 ( $A G$ 21.5, CR 23.1, LO 39.4). The populations in the second group, from the jungle of the Amazon and high jungle, showed moderate levels of resistance (defined as RR values between 5 and 10) with values ranging between 5.1 in JN and 7.1 in PU. Exception in this region was the population of PM, which showed a RR value of 28.8 to this insecticide.

Conclusions: The results demonstrate that Ae. aegypti populations in Peru present different resistance intensities to temephos, even after the suspension of its widespread use. Resistance to this larvicide should continue to be monitored because it is possible that resistance to temephos could decrease in the absence of routine selection pressures.

\section{Background}

Aedes aegypti is the main vector of arthropod-borne viral infections transmitted to humans such as dengue, yellow fever, chikungunya and Zika [1, 2]. The vector is present in tropical and subtropical regions of Southeast Asia, the Pacific and the Americas, where these viruses also circulate. In these places there are local spatial variations in the presence and density of the vector that are strongly influenced by rainfall, temperature and degree of urbanization [3]. It has been observed that this mosquito has now adapted to areas at higher altitudes than its traditional range, such as in Cochabamba (Bolivia) at 2550 m.a.s.I. [4] and in Bello (Colombia) at 2302 m.a.s.I. [5], and has colonized places such as Ica (Peru), which has an arid temperate climate with an annual rainfall of only $2 \mathrm{~mm}[6,7]$. These adaptations have led to a wide dispersal of the vector, and with it, the presence of arboviruses that often follow the same pattern of dispersal.

It is estimated that about 2.5 billion people, representing $40 \%$ of the human population worldwide, live in areas at risk of dengue transmission [8], and there are an estimated 390 million cases of dengue per year in tropical and subtropical areas [3]. In addition, in the last five years, Ae. aegypti has been responsible for the spread of chikungunya and Zika to the region of the Americas, causing significant stress to health systems, as well as social and economic disruption [9].

In Peru, the only vector of dengue, chikungunya and Zika is Ae. aegypti, which after being locally eradicated in 1958, recolonized the country in 1984 [10]. The first outbreak of dengue occurred six years later due to dengue virus serotype 1 (DENV-1) [11]. Subsequently, low-incidence outbreaks occurred until 2001, when a major outbreak occurred with 23,304 cases, confirming the circulation of the four serotypes of dengue virus (DENV) [12]. In the years 2017 and 2020, significant outbreaks occurred with 68,290 cases and 52,826 cases, respectively [13]. The first reported cases of chikungunya and Zika occurred in 2015 and 2016, respectively [14, 15].

In Peru, Aedes-borne arboviruses are present in three ecological regions: the coast, the jungle of the Amazon and the Andes Mountains $[16,17]$. However, this last region presents a diversity of altitudes that is differentiated into two areas: the Andean highlands (altitudes greater than 2300 m.a.s.I.) and high jungle (400 to 1400 m.a.s.l.; located on the eastern flank of the Andes) [18], with the Aedes-borne arboviruses only affecting areas of lower altitude. Aedes aegypti are widely distributed in 21 of Peru's 24 departments and the constitutional province of Callao, and have been identified in 
527 districts [19], where approximately 22 million people live, putting $70.4 \%$ of the Peruvian population at risk of contracting arboviruses transmitted by this vector.

The main dengue control strategy implemented in Peru until 2016 was focal treatment of larval habitats with the organophosphate (OP) insecticide temephos because of its easy dosage, application and acceptability by the community. Likewise, the adulticides used in the 1990s were the OPs fenitrothion and malathion [20]. Since the 2000s, pyrethroid (PY) insecticides have been used (cyfluthrin, deltamethrin, alpha-cypermethrin and cypermethrin) [16, 21], applied using thermal and cold fog equipment that can be manually carried or mounted on trucks. However, in 2015, Pinto et al. [22] detected resistance to PYs associated with knockdown resistance ( $k d r)$ mutations (Phe1534Cys, Val1016lle), after which the Peruvian Ministry of Health (MINSA) established the rotation of PYs with the OP malathion. For larval control, the OP temephos was switched with the insect growth regulator (IGR) pyriproxyfen because temephos shares the same mode of action as the OP malathion. The switch away from using temephos, however, was made without knowing the susceptibility status of Ae. aegyptipopulations to this insecticide.

Surveillance of insecticide resistance in arthropod vectors in Peru is an activity that falls under the Instituto Nacional de Salud (INS) and Regional Reference Laboratories (LRRs), which in the context of a decentralized health system requires coordinated work. However, many of the LRRs do not have entomology laboratories or insectaries to routinely carry out the various roles and responsibilities $[21,53]$. This situation results in the weakening of the vector surveillance and control programs, despite ongoing increases in the numbers of cases of Aedes-borne arboviruses. The continuous use of insecticides results in selective pressures that result in physiological or behavioural adaptation, a phenomenon known as resistance [54]. Insecticide resistance can lead to operational failures, requiring rotations of insecticides with different modes of action or mosaic treatments to manage insecticide resistance [36]. Ideally, these strategies should be carried out pre-emptively to preserve insecticide efficacy but also reactively to mitigate or reverse resistance [54].

This study aimed to determine the levels of resistance to temephos in 39 Peruvian populations of Ae. aegypti from the three ecological regions of Peru after having used temephos for more than 25 years, following an interruption of three years.

\section{Methods}

\section{Sampling and Study Area}

We tested the F1 or F2 generations of Ae. aegypti from colonies maintained at the Peruvian National Institute of Health (INS), which were established from eggs collected in 39 localities in the departments of Tumbes, Piura, La Libertad, San Martín, Loreto, Ucayali, Junin and Madre de Dios during April 2018 and January 2019 (Figure 1). The colonies were obtained from eggs collected with ovitraps, which were distributed every 200 linear meters covering the urban area of the locality, according to the parameters established by MINSA [23]. The ovitraps were installed in intra- and peri-domestic areas, containing a strip of paper towel as oviposition substrate $[23,24]$ and $10 \%$ hay infusion as attractant [25]. The localities sampled are located in three ecological regions showing distinct weather patterns [6], variations in the incidence of dengue $[16,17]$ and differing insecticide resistance profiles [22].

\section{Mosquito collection and laboratory rearing}

The paper strips containing eggs were left to dry for one week and then soaked in water to hatch the F0 generation [26]. The F1 and F2 generations were subsequently established in the insectary of the Laboratorio de Referencia National de Entomologia (LRNE), from Centro Nacional de Salud Pública, INS, Lima, Peru (Table 1). Humidity and temperature conditions in the insectary were maintained at $70 \pm 10 \% \mathrm{RH}$ and $26 \pm 2^{\circ} \mathrm{C}$, respectively. Aedes aegypti of the susceptible Rockefeller reference strain were used as a control for the resistance tests [27]. 
Table 1

Aedes aegypti populations used in all tests.

\begin{tabular}{|c|c|c|c|c|}
\hline Locality / Population & Code & Collection date & $N^{\circ}$ Collected eggs & Generation evaluated \\
\hline Aguas Verdes & $A G$ & Apr, 18 & 1148 & $\mathrm{~F} 1$ \\
\hline Zarumilla & ZA & Apr, 18 & 1025 & $\mathrm{~F} 1$ \\
\hline Sagaro & SA & Apr, 18 & 748 & $\mathrm{~F} 1$ \\
\hline Pampa Grande & $P G$ & Apr, 18 & 2448 & $\mathrm{~F} 1$ \\
\hline Corrales & $\mathrm{CR}$ & Apr, 18 & 833 & $\mathrm{~F} 1$ \\
\hline Cabuyal & $\mathrm{CB}$ & Apr, 18 & 233 & $\mathrm{~F} 1$ \\
\hline La Cruz & $\mathrm{CZ}$ & Apr, 18 & 187 & $\mathrm{~F} 1$ \\
\hline Mancora & MA & Apr-May, 18 & 2051 & $\mathrm{~F} 1$ \\
\hline Los Órganos & LO & Apr-May, 18 & 1573 & $\mathrm{~F} 1$ \\
\hline Bellavista & $\mathrm{BE}$ & Apr-May, 18 & 1992 & $\mathrm{~F} 1$ \\
\hline Comunidad Saludable & CS & Apr-May, 18 & 515 & $\mathrm{~F} 1$ \\
\hline Micaela Bastidas & MI & Apr-May, 18 & 468 & $\mathrm{~F} 1$ \\
\hline San José & JO & Apr-May, 18 & 1062 & $\mathrm{~F} 1$ \\
\hline Tambogrande & TA & Apr, 18 & 1360 & $\mathrm{~F} 1$ \\
\hline Chulucanas & $\mathrm{CH}$ & Apr-May, 18 & 2398 & $\mathrm{~F} 1$ \\
\hline La Esperanza & ES & Apr, 18 & 4580 & $\mathrm{~F} 1$ \\
\hline El Porvenir & PO & Apr, 18 & 3023 & $\mathrm{~F} 1$ \\
\hline Florencia de Mora & $\mathrm{FL}$ & Apr, 18 & 1673 & $\mathrm{~F} 1$ \\
\hline Laredo & LA & May, 18 & 2442 & $\mathrm{~F} 1$ \\
\hline Chao & $\mathrm{CA}$ & Apr, 18 & 1507 & $\mathrm{~F} 1$ \\
\hline Virú & VI & Apr, 18 & 781 & $\mathrm{~F} 1$ \\
\hline Moyobamba & MO & Nov-Dec, 18 & n.a & $\mathrm{F} 2$ \\
\hline Morales & MR & Nov, 18 & 900 & $\mathrm{~F} 1$ \\
\hline Banda de Shilcayo & BS & Nov, 18 & n.a & $\mathrm{F} 2$ \\
\hline Juanjui & $\mathrm{JJ}$ & Dec, 18 & 1846 & $\mathrm{~F} 1$ \\
\hline Nuevo Bambamarca & BM & Nov, 18 & n.a & $\mathrm{F} 2$ \\
\hline Tocache & TO & Nov, 18 & n.a & $\mathrm{F} 2$ \\
\hline Satipo & ST & Sep, 18 & 1216 & $\mathrm{~F} 1$ \\
\hline Iquitos & IQ & Jun, 18 & 6651 & $\mathrm{~F} 1$ \\
\hline Punchana & PU & Jun, 18 & 733 & $\mathrm{~F} 1$ \\
\hline Belén & $\mathrm{BN}$ & Jun, 18 & 775 & F1 \\
\hline
\end{tabular}




\begin{tabular}{|lllll|}
\hline Locality / Population & Code & Collection date & $\mathbf{N}^{\circ}$ Collected eggs & Generation evaluated \\
\hline San Juan Bautista & JN & Jun, 18 & 1876 & F1 \\
\hline San José & SY & Aug, 18 & 324 & F1 \\
\hline Yarinacocha & YA & Aug, 18 & 2342 & F1 \\
\hline Callería & PL & Aug, 18 & 2123 & F1 \\
\hline José Carlos Mariátegui & PA & Aug, 18 & 1487 & F1 \\
\hline Manantay & MY & Aug, 18 & 1391 & F1 \\
\hline San Fernando & FE & Aug, 18 & 562 & F1 \\
\hline Puerto Maldonado & PM & Jan, 19 & 891 & \\
\hline
\end{tabular}

\section{Larvicide Susceptibility Testing}

Dose-response susceptibility tests were performed with temephos following WHO recommendations [28]. The larvae were exposed to a wide range of the insecticide concentrations in order to evaluate the larvicidal activity and thereby determine the values of the lethal concentration (LC) $\mathrm{LC}_{50}$ and $\mathrm{LC}_{95}$ for each study population. Four replicates per concentration, and eleven concentrations were evaluated with 20 3rd -stage larvae (L3) in $100 \mathrm{~mL}$ of insecticide solution per replicate. Insecticide solutions were prepared with temephos active ingredient (Chem Service, West Chester, USA), using a concentration range of 0.004 to $0.324 \mathrm{mg} / \mathrm{mL}$ for field populations, and 0.002 to $0.012 \mathrm{mg} / \mathrm{mL}$ for the Rockefeller strain. Simultaneously, a control group with 4 replicates exposed only to $600 \mu \mathrm{L}$ of ethanol solvent was evaluated [28]. Each test was carried out on three different days to ensure the reproducibility of the method and consistency of the results $[28,29]$.

\section{Data Analysis}

The values for $\mathrm{LC}_{50}$ and $\mathrm{LC}_{95}$ were calculated from a log dosage-probit mortality regression line using probit analysis, Polo-PC statistics package [30] for each population. Resistance ratios (RRs) were also calculated to define the intensity of resistance in the field populations. To calculate the $\mathrm{RR}_{50}(i=50)$ and the $\mathrm{RR}_{95}(i=95)$ equation 1 was used:

$R R_{i}=\frac{L C_{i(\text { field })}}{L C_{i(\text { RockefellerLineage })}} \ldots$ Equation 1

The population was considered susceptible when the RR< 5; when the RR was between 5 and 10 , the population was considered to have moderate resistance; and when the $R R \geq 10$, the population was considered highly resistant.

\section{Results}

Thirty-nine mosquito populations were obtained from localities with different incidence of arboviruses and located in three ecological regions of Peru. The F1 and F2 generations were evaluated and a total of 37,440 L3 larvae were tested across all bioassays.

Table 2 and Figure 2 show the values of the $L_{50}$ and $L C_{95}$, the resistance ratios $\left(R R_{50}\right.$ and $\left.R R_{95}\right)$ and the slope of the probit regression lines for the insecticide temephos in the 39 populations of Ae. aegypti. The differences between the $\mathrm{RR}_{95}$ of all populations were analysed according to the criteria of Mazzarri and Georghiou [31] and Sá et al. [29], and showed that the three regions could be grouped into two groups: coastal and jungle (including the Amazon and high jungle). In the coastal group, the populations were mostly highly resistant to temephos (RR>10), with three populations 
showing values greater than 20 (AG 21.5, CR 23.1, LO 39.4). Some populations (PG, MI, TA, BE, CS, ES and LA) showed moderate levels of resistance $(5 \leq \mathrm{RR}<10)$ and only four populations $(\mathrm{JO}, \mathrm{CH}, \mathrm{CA}$ and $\mathrm{VI})$ were considered susceptible $(R R<5)$. In the jungle group, most of the populations showed moderate levels of resistance $(5 \leq R R<10)$ with values between 5.1 in JN and 7.1 in PU, while some populations were considered susceptible $(R R<5)$ with values between 2.2 in $\mathrm{MO}$ and 4.9 in YA and PA, with the notable exception of the population of PM, which was considered highly resistant with a RR value of 28.8 . 
Table 2

Temephos susceptibility profiles of Peruvian populations showing slope values, Lethal Concentration values (LC), and Resistance Ratios (RR).

\begin{tabular}{|c|c|c|c|c|c|c|c|c|c|c|c|}
\hline \multirow[t]{3}{*}{ Department } & \multirow{2}{*}{$\begin{array}{l}\text { Lineage / } \\
\text { Population }\end{array}$} & \multirow[t]{2}{*}{ Code } & \multirow[t]{2}{*}{$\mathbf{F}$} & \multirow[t]{2}{*}{$\mathbf{N}$} & \multicolumn{4}{|c|}{ LC (95\% Cl) } & \multicolumn{3}{|c|}{ RR } \\
\hline & & & & & Slope & LC50 & & LC95 & & $\mathrm{RR}_{50}$ & $\mathrm{RR}_{95}$ \\
\hline & Rockefeller & & & 2880 & 5.67 & 0.005 & $\begin{array}{l}(0.004- \\
0.006)\end{array}$ & 0.01 & $\begin{array}{l}(0.009- \\
0.011)\end{array}$ & 1.0 & 1.0 \\
\hline \multirow[t]{7}{*}{ Tumbes } & Aguas Verdes & $A G$ & $\mathrm{~F} 1$ & 2880 & 2.50 & 0.047 & $\begin{array}{l}(0.045- \\
0.050)\end{array}$ & 0.215 & $\begin{array}{l}(0.193- \\
0.245)\end{array}$ & 9.4 & 21.5 \\
\hline & Zarumilla & ZA & $\mathrm{F} 1$ & 2880 & 3.22 & 0.036 & $\begin{array}{l}(0.034- \\
0.037)\end{array}$ & 0.116 & $\begin{array}{l}(0.108- \\
0.127)\end{array}$ & 7.2 & 11.6 \\
\hline & Sagaro & SA & $\mathrm{F} 1$ & 2880 & 3.65 & 0.039 & $\begin{array}{l}(0.038- \\
0.041)\end{array}$ & 0.110 & $\begin{array}{l}(0.103- \\
0.119)\end{array}$ & 7.8 & 11.0 \\
\hline & $\begin{array}{l}\text { Pampa } \\
\text { Grande }\end{array}$ & PG & $\mathrm{F} 1$ & 2880 & 3.72 & 0.032 & $\begin{array}{l}(0.031- \\
0.033)\end{array}$ & 0.089 & $\begin{array}{l}(0.083- \\
0.095)\end{array}$ & 6.4 & 8.9 \\
\hline & Corrales & $\mathrm{CR}$ & $\mathrm{F} 1$ & 2880 & 2.28 & 0.044 & $\begin{array}{l}(0.041- \\
0.046)\end{array}$ & 0.231 & $\begin{array}{l}(0.201- \\
0.273)\end{array}$ & 8.8 & 23.1 \\
\hline & Cabuyal & $\mathrm{CB}$ & $\mathrm{F} 1$ & 2880 & 2.42 & 0.028 & $\begin{array}{l}(0.026- \\
0.030)\end{array}$ & 0.135 & $\begin{array}{l}(0.122- \\
0.152)\end{array}$ & 5.6 & 13.5 \\
\hline & La Cruz & $\mathrm{CZ}$ & $\mathrm{F} 1$ & 2880 & 3.74 & 0.056 & $\begin{array}{l}(0.054- \\
0.058)\end{array}$ & 0.154 & $\begin{array}{l}(0.145- \\
0.166)\end{array}$ & 11.2 & 15.4 \\
\hline \multirow[t]{8}{*}{ Piura } & Mancora & MA & $\mathrm{F} 1$ & 2880 & 3.7 & 0.071 & $\begin{array}{l}(0.069- \\
0.074)\end{array}$ & 0.199 & $\begin{array}{l}(0.181- \\
0.222)\end{array}$ & 14.2 & 19.9 \\
\hline & Los Organos & LO & $\mathrm{F} 1$ & 2880 & 3.01 & 0.111 & $\begin{array}{l}(0.090- \\
0.136)\end{array}$ & 0.394 & $\begin{array}{l}(0.321- \\
0.484)\end{array}$ & 22.2 & 39.4 \\
\hline & Bellavista & $\mathrm{BE}$ & $\mathrm{F} 1$ & 2880 & 3.05 & 0.025 & $\begin{array}{l}(0.024- \\
0.026)\end{array}$ & 0.086 & $\begin{array}{l}(0.080- \\
0.094)\end{array}$ & 5.0 & 8.6 \\
\hline & $\begin{array}{l}\text { Comunidad } \\
\text { Saludable }\end{array}$ & $\mathrm{CS}$ & $\mathrm{F} 1$ & 2880 & 2.75 & 0.024 & $\begin{array}{l}(0.022- \\
0.026)\end{array}$ & 0.094 & $\begin{array}{l}(0.087- \\
0.103)\end{array}$ & 4.8 & 9.4 \\
\hline & $\begin{array}{l}\text { Micaela } \\
\text { Bastidas }\end{array}$ & MI & $\mathrm{F} 1$ & 2880 & 3.36 & 0.020 & $\begin{array}{l}(0.018- \\
0.021)\end{array}$ & 0.060 & $\begin{array}{l}(0.057- \\
0.065)\end{array}$ & 4.0 & 6.0 \\
\hline & San Jose & JO & $\mathrm{F} 1$ & 2880 & 3.88 & 0.016 & $\begin{array}{l}(0.015- \\
0.016)\end{array}$ & 0.041 & $\begin{array}{l}(0.039- \\
0.045)\end{array}$ & 3.2 & 4.1 \\
\hline & Tambogrande & TA & $\mathrm{F} 1$ & 2880 & 4.58 & 0.025 & $\begin{array}{l}(0.024- \\
0.026)\end{array}$ & 0.057 & $\begin{array}{l}(0.054- \\
0.060)\end{array}$ & 5.0 & 5.7 \\
\hline & Chulucanas & $\mathrm{CH}$ & $\mathrm{F} 1$ & 2880 & 4.02 & 0.015 & $\begin{array}{l}(0.014- \\
0.015)\end{array}$ & 0.038 & $\begin{array}{l}(0.036- \\
0.041)\end{array}$ & 3.0 & 3.8 \\
\hline \multirow[t]{3}{*}{ La Libertad } & La Esperanza & ES & $\mathrm{F} 1$ & 2880 & 2.54 & 0.018 & $\begin{array}{l}(0.016- \\
0.019)\end{array}$ & 0.078 & $\begin{array}{l}(0.071- \\
0.087)\end{array}$ & 3.6 & 7.8 \\
\hline & El Porvenir & PO & $\mathrm{F} 1$ & 2880 & 2.59 & 0.025 & $\begin{array}{l}(0.023- \\
0.026)\end{array}$ & 0.107 & $\begin{array}{l}(0.097- \\
0.119)\end{array}$ & 5.0 & 10.7 \\
\hline & $\begin{array}{l}\text { Florencia de } \\
\text { Mora }\end{array}$ & $\mathrm{FL}$ & $\mathrm{F} 1$ & 2880 & 2.81 & 0.029 & $\begin{array}{l}(0.028- \\
0.031)\end{array}$ & 0.113 & $\begin{array}{l}(0.103- \\
0.125)\end{array}$ & 5.8 & 11.3 \\
\hline
\end{tabular}




\begin{tabular}{|c|c|c|c|c|c|c|c|c|c|c|c|}
\hline \multirow[t]{5}{*}{ Department } & \multirow{3}{*}{$\begin{array}{l}\text { Lineage / } \\
\text { Population } \\
\text { Laredo }\end{array}$} & \multirow{3}{*}{$\begin{array}{l}\text { Code } \\
\text { LA }\end{array}$} & \multirow{3}{*}{$\begin{array}{l}\mathbf{F} \\
\mathrm{F} 1\end{array}$} & \multirow{3}{*}{$\begin{array}{l}\mathbf{N} \\
2880\end{array}$} & \multicolumn{4}{|c|}{ LC (95\% Cl) } & \multicolumn{3}{|c|}{ RR } \\
\hline & & & & & \multirow{2}{*}{$\begin{array}{l}\text { Slope } \\
3.37\end{array}$} & \multicolumn{2}{|l|}{ LC50 } & \multicolumn{2}{|l|}{ LC95 } & \multirow{2}{*}{$\begin{array}{l}\mathbf{R R}_{\mathbf{5 0}} \\
4.2\end{array}$} & \multirow{2}{*}{$\begin{array}{l}\mathrm{RR}_{\mathbf{9 5}} \\
6.6\end{array}$} \\
\hline & & & & & & 0.021 & $\begin{array}{l}(0.020- \\
0.022)\end{array}$ & 0.066 & $\begin{array}{l}(0.061- \\
0.071)\end{array}$ & & \\
\hline & Chao & $\mathrm{CA}$ & $\mathrm{F} 1$ & 2880 & 7.18 & 0.010 & $\begin{array}{l}(0.010- \\
0.010)\end{array}$ & 0.021 & $\begin{array}{l}(0.020- \\
0.023)\end{array}$ & 2.0 & 2.1 \\
\hline & Viru & VI & $\mathrm{F} 1$ & 2880 & 5.63 & 0.011 & $\begin{array}{l}(0.011- \\
0.012)\end{array}$ & 0.022 & $\begin{array}{l}(0.022- \\
0.024)\end{array}$ & 2.2 & 2.2 \\
\hline \multirow[t]{6}{*}{ San Martín } & Moyobamba & MO & $\mathrm{F} 2$ & 2880 & 4.39 & 0.009 & $\begin{array}{l}(0.009- \\
0.010)\end{array}$ & 0.022 & $\begin{array}{l}(0.021- \\
0.024)\end{array}$ & 1.8 & 2.2 \\
\hline & Morales & MR & $\mathrm{F} 1$ & 2880 & 4.00 & 0.021 & $\begin{array}{l}(0.021- \\
0.022)\end{array}$ & 0.055 & $\begin{array}{l}(0.052- \\
0.059)\end{array}$ & 4.2 & 5.5 \\
\hline & $\begin{array}{l}\text { Banda de } \\
\text { Shilcayo }\end{array}$ & BS & $\mathrm{F} 2$ & 2880 & 4.33 & 0.023 & $\begin{array}{l}(0.022- \\
0.024)\end{array}$ & 0.055 & $\begin{array}{l}(0.053- \\
0.059)\end{array}$ & 4.6 & 5.5 \\
\hline & Juanjui & $\mathrm{JJ}$ & $\mathrm{F} 1$ & 2880 & 3.65 & 0.010 & $\begin{array}{l}(0.009- \\
0.010)\end{array}$ & 0.042 & $\begin{array}{l}(0.039- \\
0.047)\end{array}$ & 2.0 & 4.2 \\
\hline & $\begin{array}{l}\text { Nuevo } \\
\text { Bambamarca }\end{array}$ & BM & $\mathrm{F} 2$ & 2880 & 4.85 & 0.011 & $\begin{array}{l}(0.010- \\
0.011)\end{array}$ & 0.023 & $\begin{array}{l}(0.022- \\
0.025)\end{array}$ & 2.2 & 2.3 \\
\hline & Tocache & TO & $\mathrm{F} 2$ & 2880 & 4.14 & 0.010 & $\begin{array}{l}(0.009- \\
0.010)\end{array}$ & 0.024 & $\begin{array}{l}(0.023- \\
0.026)\end{array}$ & 2.0 & 2.4 \\
\hline Junin & Satipo & ST & $\mathrm{F} 1$ & 2880 & 3.45 & 0.019 & $\begin{array}{l}(0.018- \\
0.020)\end{array}$ & 0.058 & $\begin{array}{l}(0.054- \\
0.062)\end{array}$ & 3.8 & 5.8 \\
\hline \multirow[t]{4}{*}{ Loreto } & Iquitos & IQ & $\mathrm{F} 1$ & 2880 & 4.02 & 0.026 & $\begin{array}{l}(0.025- \\
0.027)\end{array}$ & 0.067 & $\begin{array}{l}(0.063- \\
0.071)\end{array}$ & 5.2 & 6.7 \\
\hline & Punchana & PU & $\mathrm{F} 1$ & 2880 & 4.73 & 0.032 & $\begin{array}{l}(0.031- \\
0.033)\end{array}$ & 0.071 & $\begin{array}{l}(0.068- \\
0.075)\end{array}$ & 6.4 & 7.1 \\
\hline & Belen & $\mathrm{BN}$ & $\mathrm{F} 1$ & 2880 & 4.36 & 0.023 & $\begin{array}{l}(0.022- \\
0.024)\end{array}$ & 0.054 & $\begin{array}{l}(0.052- \\
0.057)\end{array}$ & 4.6 & 5.4 \\
\hline & $\begin{array}{l}\text { San Juan } \\
\text { Bautista }\end{array}$ & $\mathrm{JN}$ & $\mathrm{F} 1$ & 2880 & 4.18 & 0.021 & $\begin{array}{l}(0.020- \\
0.022)\end{array}$ & 0.051 & $\begin{array}{l}(0.048- \\
0.054)\end{array}$ & 4.2 & 5.1 \\
\hline \multirow[t]{6}{*}{ Ucayali } & $\begin{array}{l}\text { San Jose- } \\
\text { Yarinacocha }\end{array}$ & SY & $\mathrm{F} 1$ & 2880 & 3.89 & 0.017 & $\begin{array}{l}(0.017- \\
0.018)\end{array}$ & 0.069 & $\begin{array}{l}(0.063- \\
0.076)\end{array}$ & 3.4 & 6.9 \\
\hline & Yarinacocha & YA & $\mathrm{F} 1$ & 2880 & 4.21 & 0.02 & $\begin{array}{l}(0.019- \\
0.020)\end{array}$ & 0.049 & $\begin{array}{l}(0.046- \\
0.052)\end{array}$ & 4.0 & 4.9 \\
\hline & Callería & $P L$ & $\mathrm{~F} 1$ & 2880 & 4.02 & 0.015 & $\begin{array}{l}(0.014- \\
0.015)\end{array}$ & 0.038 & $\begin{array}{l}(0.036- \\
0.041)\end{array}$ & 3.0 & 3.8 \\
\hline & $\begin{array}{l}\text { José Carlos } \\
\text { Mariátegui }\end{array}$ & PA & $\mathrm{F} 1$ & 2880 & 3.83 & 0.018 & $\begin{array}{l}(0.018- \\
0.019)\end{array}$ & 0.049 & $\begin{array}{l}(0.046- \\
0.053)\end{array}$ & 3.6 & 4.9 \\
\hline & Manantay & MY & $\mathrm{F} 1$ & 2880 & 3.58 & 0.018 & $\begin{array}{l}(0.017- \\
0.019)\end{array}$ & 0.052 & $\begin{array}{l}(0.048- \\
0.056)\end{array}$ & 3.6 & 5.2 \\
\hline & San Fernando & $\mathrm{FE}$ & $\mathrm{F} 1$ & 2880 & 5.07 & 0.015 & $\begin{array}{l}(0.014- \\
0.015)\end{array}$ & 0.031 & $\begin{array}{l}(0.030- \\
0.033)\end{array}$ & 3.0 & 3.1 \\
\hline
\end{tabular}




\begin{tabular}{|c|c|c|c|c|c|c|c|c|c|c|c|}
\hline \multirow[t]{2}{*}{ Department } & \multirow{2}{*}{$\begin{array}{l}\text { Lineage / } \\
\text { Population }\end{array}$} & \multirow[t]{2}{*}{ Code } & \multirow[t]{2}{*}{$\mathrm{F}$} & \multirow[t]{2}{*}{$\mathbf{N}$} & \multicolumn{4}{|c|}{ LC (95\% Cl) } & \multicolumn{3}{|c|}{ RR } \\
\hline & & & & & Slope & LC50 & & LC95 & & $\mathrm{RR}_{50}$ & $\mathrm{RR}_{95}$ \\
\hline $\begin{array}{l}\text { Madre de } \\
\text { Dios }\end{array}$ & $\begin{array}{l}\text { Puerto } \\
\text { Maldonado }\end{array}$ & PM & $\mathrm{F} 1$ & 2880 & 2.11 & 0.048 & $\begin{array}{l}(0.045- \\
0.051)\end{array}$ & 0.288 & $\begin{array}{l}(0.243- \\
0.355)\end{array}$ & 9.6 & 28.8 \\
\hline
\end{tabular}

However, the resistance ratios of the populations were heterogeneous even within the same department. In Tumbes, for example, most populations were highly resistant to temephos ( $R R>10)$, except for the PG population $(R R=8.9)$ which showed moderate resistance to this insecticide. On the other hand, Piura had two populations (MA and LO) that exhibited high RR values $(R R>19)$, but also had two susceptible populations with low values $(R R<5)$. In La Libertad, the resistance ratios varied between 2.1 in CA to 11.3 in FL, showing that this department also presented heterogeneous resistance ratios, but with two populations where the lowest values were detected $(\mathrm{RR}<2.5)$. The departments of San Martin, Junin, Loreto and Ucayali were more homogeneous, with values between 2.2 in MO and 7.1 in PU. However, despite the generally lower RR values in the jungle areas, in the jungle department of Madre de Dios, the PM population showed a RR value of 28.8. However, the resistance ratios of the populations were heterogenous even within in the same locality. Populations ( $A G, Z A, S A, P G, C R, C B, P O, F L$ and PM) with the moderate level of resistance $(5 \leq R R<10)$ in $R_{50}$ but showed highly resistant to temephos (RR > 10) in $\mathrm{RR}_{95}$ and populations (CS, MI, ES, LA, MR, BS, ST, BN, JN, SY and $M Y$ ) with low values in $R_{50}$ but showed moderate resistance in $R R_{95}$. Populations $C Z, M A$ and $L O$, due to their highly resistant to temephos were more homogeneous, with high values of $\operatorname{RR}_{50}(11.2,14.2$ and 22.2$)$ and $R_{95}(15.4,19.9$ and 39.4). Some populations ( $P G, B E, T A, I Q$ and $P U)$ showed moderate level of resistance $(5 \leq R R<10)$ and 12 populations ( JO, CH, CA, VI, MO, JJ, BM, TO, YA, PL, PA and FE), were considered more susceptible ( $R R<5)$ in both $\mathrm{RR}_{50}$ and $\mathrm{RR}_{95}$. In general, jungle localities were more homogeneous.

In Table 2 and Figure 3, the slope values of the probit regression lines of the field populations were lower than those obtained with the Rockefeller lineage, except in the CA population (slope=7.18), confirming the heterogeneity of temephos resistance in the field strains in relation to the reference strain.

\section{Discussion}

As part of a national strategic plan against dengue, chikungunya and Zika, a national survey to ascertain the susceptibility of $A e$. aegypti to temephos was undertaken. The Peruvian INS, in coordination with Regional Health Directorates, surveyed 39 dengue endemic localities from April 2018 to January 2019. Overall, Peruvian populations of Ae. aegypti showed variable levels of resistance to temephos. According to the results these populations were clustered into two groups: 1) coastal populations with moderate to high resistance to temephos, and 2) jungle populations, which showed moderate resistance and some susceptibility, except for the Puerto Maldonado population which was highly resistant.

Higher levels of resistance to temephos were detected in coastal populations than in jungle populations, despite the fact that the northern coast was recolonized by Ae. aegypti ten years after the Peruvian Amazon [32, 33]. The reasons underlying this difference in susceptibility are likely diverse. For example, the departments along the northern coast of Peru were the most affected by the El Niño climatic phenomenon (1997-1998), with heavy rains that caused an increase in malaria and dengue cases [34,35]. This situation led to the establishment of prevention and control activities, including insecticide space spraying and indoor residual spraying, mapping and treatment of larval habitats (including chemical control with temephos), and campaigns to eliminate potential larval habitats. These activities were carried out periodically in 333 localities in the departments of Tumbes, Piura, Lambayeque, and La Libertad, with the goal of eliminating larval habitats in urban, peri-urban, and rural areas. In addition, there is a growing urban concentration on the 
coast, without planning or organization and with insufficient basic sanitation, due to constant migration from other regions due to violence, lack of job opportunities, education, access to technological resources, and poverty [35]. This rapid, unplanned urbanization favors the introduction and establishment of Ae. aegypti. However, the Peruvian coastline is formed by a desert strip interrupted by valleys whose main characteristic is the scarcity of rainfall [6], which is should serve as a limiting factor for the transmission of arboviruses in this region with the important exception of the north coast, which experiences high temperatures and rainfall in the summer due to its proximity to the equator [17]. However, the potential benefit of this arid climate is overcome by the presence of larval habitats inside homes as a consequence of inadequate water storage due to deficient piped water supply in urban centers $[16,36]$. Evidence of this can be seen in the types of larval habitats that predominate in and around homes, including water storage drums, cylinders, wells and flower vases [7]. As a result, access, availability and quality of water is an environmental determinant that creates conditions for the proliferation of vectors and transmission of arboviruses [37], as demonstrated by the Ministry of Health of Peru, who reported in 2016 that inadequate access to water was associated with $41.2 \%$ of cases of dengue [38].

The Peruvian Amazon presents different ecosystems than those seen on the coast. These jungle areas typically include humid and rainy tropical forests [6]. In this region, due to the constant rainfall, there is a greater abundance of potential larval habitats, especially those known as "los inservibles" (discarded objects, passively filled with rainwater). Unlike along the coast, these larval habitats are typically peri-domestic and unintentionally hold water [39]. In contrast to the urbanization along the coast, the jungle is the least populated region of the country and accounts for only $10 \%$ of the national population, and the infrastructure of Amazonian villages often reflects inadequate access to basic services, education and health [40]. The city of Puerto Maldonado is the capital of the Amazonian department of Madre de Dios, located in the southeastern part of the country. In this city, the Ae. aegypti population was the only one in the Peruvian Amazon that presented high resistance to temephos. The vector was introduced in this city in 1999 [41], fifteen years after the first record in the Peruvian jungle in 1984 [10]. Dengue cases were sporadic in the period from 2000 to 2016 , with only one major outbreak reported in 2010 with 2952 recorded cases [42]. This low burden of dengue is supported by the findings of Salmón-Mulanovich et al. [43], who found low seroprevalence to DENV in a retrospective study conducted in Puerto Maldonado in 2018. This low disease burden suggests that vector control activities were not routine or intense, and that the local Ae. aegypti population has not experienced strong selection pressure with the larvicide temephos. The explanation for the high temephos resistance detected in this study could be due to the fact that the vector has spread across the border from Brazil and Bolivia. On the Brazilian side, the Ae. aegypti population from Rio Branco (Acre State) is highly resistant to temephos [44] and similarly, on the Bolivian side, the Ae. aegypti population in the border city of Cobija (department of Pando) has moderate resistance to temephos [45].

It is also important to consider that at the national level, the use of pesticides in the agricultural sector in Peru is intense, with the most widely used insecticides being organophosphates (OPs) [46]. Historically, organochlorines (OCs) were used between 1940-1950 (dichloro diphenyl trichloroethane [DDT], benzene hexachloride [BHC] and toxaphene) and the OPs parathion and methamidophos were introduced in 1950 and were used for several decades, with parathion used until 2005 [46] and methamidophos until 2018-19 [47]. In the 2000s, pyrethroids (deltamethrin, cypermethrin and alphacypermethrin) and carbamates (CA) (carbofuran, methomyl, carbosulfan and carbaryl) were introduced [46, 47]. In a study conducted in 2012, it was reported that $43 \%$ of farmers preferred to use OPs because they had a broad spectrum of action (contact, ingestion and fumigant effects) [48]. It is important to note that these pesticides were widely used on cotton, corn and potato crops in the northern and central coastal valleys, as well as in the Andes Mountains. Another important consideration is the illegal trade of pesticides through smuggling (mainly on the northern border), street sales, adulteration and counterfeiting of products, especially in the northern coast, central and southern parts of the Andes Mountains [49]. The continuous use of pesticides in agriculture has led to pest resistance to OCs and OPs due to misuse of pesticides and lack of pesticide management [46]. The agricultural sector is using the same classes of insecticides

Page 10/18 
that are being used for public health, so mosquitoes and other non-target insects may experience pressure from insecticides used in agriculture, resulting in the selection of populations that exhibit resistance to multiple insecticides [50].

The results of the present investigation demonstrate that Peruvian Ae. aegypti populations display a diversity of resistance to temephos. These results are consistent with resistance patterns observed in other field populations that have had intense selection pressure with temephos [51]. In Peru, temephos had been used for more than 25 years and it is thus not surprising that in some areas, resistance to this insecticide has reached very high levels. However, it is not possible to estimate or quantify the evolution of this resistance due to the lack of baseline information, a fact that is corroborated by the absence of data from Peru in the findings of the review of resistance prepared by Moyes et al. [52]. Resistance to temephos has been reported worldwide and at high levels in Tamil Nadu (India) [55], Caldas (Colombia) [56], Pernambuco (Brazil) [57], Martinique [58] and Bahia (Brazil) [59]; at moderate levels as in Tocantins (Brazil) [29], Laos (Asia) [60], Paraná (Brazil) [61], Quindío (Colombia) [62], Delhi (India) [63], Sao Paulo and Northeast Region (Brazil) [64], and susceptibility has been reported in Malaysia [65], Santiago Island (Cape Verde) [66] and Phitsanulok province in Thailand [50].

Chemical control of Ae. aegypti with temephos in Peru was continuous until 2015 when it was replaced by pyriproxyfen [67]; this could explain the moderate and low levels of resistance found in the populations of Pampa Grande, Bellavista, and Comunidad Saludable among others. This suggests that resistance to temephos is unstable in the absence of continuous selection pressure; a fact that is corroborated by the findings of Wirth and Georghiou [51], who detected significant decreases in the levels of resistance to temephos in the British Virgin Islands (Tortola) from a RR of 46.8 in 1985 [24] to 12.1 in 1992-93 [68] and then to 6.3 in 1995-96 [69] after the interruption of its use for more than 10 years. Similarly, Conde et al. [56] observed in Colombia (Caldas) the reduction of temephos resistance from RRs of 13.27 and 11.48 in 2007 to 4.75 and 5.61 in 2011 after discontinuation of its use for four years. Similarly, Brazil (Juazeiro do Norte) [70] observed a decrease in resistance to temephos from a RR of 10.4 to 7.2 after 7 years when this larvicide was replaced by Bacillus thuringiensis israelensis (Bti) and Rahman et al. [71] observed in Rio de Janeiro in the municipality of Campos dos Goytacazes the reduction of temephos resistance from a RR of 7.8 in 2001 to 2.6 in 2016 after discontinuation of its use for 15 years and detected significant decrease in the levels of resistance to temephos in the municipality of Itaperona from a RR of 25.6 in 2011 to 7.3 in 2016 after this larvicide was substituted by IGR. Consequently, rotating to a new insecticide with a different mode of action could be advantageous for temephos resistance management. WHO recommends the following compounds as alternative larvicides: Bti, diflubenzuron, methoprene, novaluron, pyriproxyfen and spinosad.

Following the observed resistance of Peruvian Ae. aegypti to pyrethroids, the OP malathion is being reintroduced [67]. It is uncertain how long this insecticide will remain effective if resistance to temephos has already been demonstrated or if there is cross-resistance between temephos and malathion. Wirth and Georghiou [51] suggested that resistance to malathion did not increase significantly under selection pressure with temephos and that adulticides exerted lower selection pressure than larvicides [24]. If this is indeed the case, it is reasonable to believe that malathion may still be effective in Peru, which is important considering the few chemical options available in Peru for vector control.

An important limitation to this study was the lack of additional evaluations that would allow us to better understand the evolution of resistance to temephos, as well as the characterization of the observed resistance by molecular and enzymatic methods. On this last point, Rodriguez et al. [72] in a study with Latin American populations, found that a Peruvian Ae. aegypti population presented variations in the intensity of resistance to different OPs (temephos RR=30, malathion 1.5, fenthion 6.6, pirimiphos-methyl 10, fenitrothion 1.1 and chlorpyrifos 4.3), with elevated activity of esterases related to resistance to temephos, while mono-oxygenases were associated with resistance to pirimiphosmethyl and chlorpyrifos. 


\section{Conclusions}

The results of this study demonstrate that Ae. aegypti populations in Peru have different levels of resistance to temephos, even after its widespread use was suspended, spanning the spectrum from susceptible to high levels of resistance. It is necessary to continue monitoring resistance to this larvicide to understand if in the absence of widespread use, susceptibility to temephos may be recovered in the future. The implementation of insecticide resistance management strategies is important to preserve the efficacy of insecticides used in public health, and it is necessary to carry out vector control with multisectoral components that can improve the effectiveness of the Ae. aegypticontrol program in Peru.

\section{Declarations}

\section{Acknowledgments}

We thank Hugo Encinas, Miguel Hernández, Ruth Quiroz, Norma García, Rosa Mosqueda from the Entomology laboratory of the Instituto Nacional de Salud of Perú. We also thank Salvador Villegas and Máximo Lañas from the Regional Health Directorate of Piura, Percy Purizaga from the Regional Health Directorate of Tumbes, Janet Gozzer ${ }^{\dagger}$ from the Regional Health Directorate of La Libertad, Etty López and Juan Ruiz ${ }^{\dagger}$ from the Regional Health Directorate of San Martín, Ana Manrique from the Regional Health Directorate of Madre de Dios, Victor Giu from the Regional Health Directorate of Ucayalí and Carmen Sinti from the Centro de Investigación en Enfermedades Tropicales "Maxime Kuczynski"-CIETROP/INS. Iquitos, Perú.

Disclaimer: The findings and conclusions in this paper are those of the authors and do not necessarily represent the official position of the Centers for Disease Control and Prevention.

\section{Authors' contributions}

MP and JBP conceived and designed the study. MP, JP, PY and AC carried out the field work. MP, LD, QA, PY and AC carried out the laboratory work. MP and LD analyzed and interpreted the data. MP, AL and JBP wrote the manuscript. All authors read and approved the final manuscript.

\section{Funding}

Not applicable.

\section{Availability of data and materials}

All data generated or analyzed during this study are included in this published article.

\section{Ethics approval and consent to participate}

Not applicable.

\section{Consent for publication}

Not applicable.

\section{References}


1. Hamid PH, Ninditya VI, Ghiffari A, Taubert A, Hermosilla C. The V1016G mutation of the voltage-gated sodium channel (VGSC) gene contributes to the insecticide resistance of Aedes aegypti from Makassar, Indonesia. Parasitol Res. 2020;119(7):2075-83.

2. Fontana JD, Ferreira RL, Zuccolotto T, de Borba Dallagassa C, Wielewski LP, Chalcoski BMS, et al. Accelerating the Morphogenetic Cycle of the Viral Vector Aedes aegypti Larvae for Faster Larvicidal Bioassays. Biomed Res Int 29 de agosto de. 2020;2020:1-9.

3. Bhatt S, Gething PW, Brady OJ, Messina JP, Farlow AW, Moyes CL, et al. The global distribution and burden of dengue. Nature. 2013;496(7446):504-7.

4. Castillo-Quino R, Vallejo-Castro E, Camacho-Aliaga AV, Canelas-Urey HI. Adaptación del mosquito Aedes aegypti a 2 550 m s.n.m. Cochabamba, Bolivia. Febrero 2016. Gac Medica Boliv. 2018;41(1):24-30.

5. Ruiz-López F, González-Mazo A, Vélez-Mira A, Gómez GF, Zuleta L, Uribe S, et al. Presencia de Aedes (Stegomyia) aegypti (Linnaeus, 1762) y su infección natural con el virus del dengue en alturas no registradas para Colombia. Biomédica. 2016;36(2):303-8.

6. Castro A, Davila C, Laura W, Cubas F, Ávalos G, López Ocaña C, et al. Climas del Perú. Mapa de clasificación climática nacional. Servicio Nacional de Meteorología e Hidrología del Perú; 2020.

7. Requena-Zúñiga E, Mendoza-Uribe L, Guevara-Saravia M. New distribution areas of Aedes aegypti in Peru]. Rev Peru Med Exp Salud Publica. 2016;33(1):171-2.

8. Vera-Maloof FZ, Saavedra-Rodriguez K, Elizondo-Quiroga AE, Lozano-Fuentes S, Black IVWC. Coevolution of the Ile1,016 and Cys1,534 Mutations in the Voltage Gated Sodium Channel Gene of Aedes aegypti in Mexico. PLoS Negl Trop Dis. 2015;9(12).

9. Organización Mundial de la Salud [OMS]. Respuesta mundial para el control de vectores - enfoque integrado para el control de las enfermedades de transmisión vectorial. 2017.

10. Andrade CS, Cáceres AG, Vaquerizo A, Ibañez-Bernal S, Cachay LS. Reappearance of Aedes aegypti (Diptera: Culicidae) in Lima, Peru. Mem Inst Oswaldo Cruz. 2001;96(5):657-8.

11. Phillips I, Need J, Escamilla J, Colán E, Sánchez S, Rodríguez M, et al. Dengue in the Peruvian Amazon. Bull PAHO. 1992;26(3):201-7.

12. Mostorino ER, Rosas AA, Gutierrez PV, Anaya RE, Cobos ZM, García MM. Manifestaciones clínicas y distribución geográfica de los serotipos del dengue en el Perú año 2001. Rev Peru Med Exp Salud Publica. 2002;19(4):171-80.

13. Centro Nacional de Epidemiologia Prevención y Control de Enfermedades. Sala de situación de Salud - Perú a la SE 26 - 2021. Ministerio de Salud del Perú. 2021.

14. Mateo S. Situación epidemiológica del Chikungunya en el Perú, SE 07 - 2017. Bol Epidemiol del Peru. 2017;26(7):1388-90.

15. Mateo S. Situación epidemiológica del Zika en el Perú, a la SE 07 2017. Bol Epidemiol del Peru. 2017;26(7):1385-7.

16. Cabezas C, Fiestas V, García-Mendoza M, Palomino M, Mamani E, Donaires F. [Dengue in Peru: a quarter century after its reemergence]. Rev Peru Med Exp Salud Publica. 2015;32(1):146-56.

17. Chowell G, Cazelles B, Broutin H, Munayco CV. The influence of geographic and climate factors on the timing of dengue epidemics in Perú, 1994-2008. BMC Infect Dis. 2011;11(1):164.

18. Instituto Geográfico Nacional. Historia Del Instituto Geográfico Nacional. Enero. 2015. 195 p.

19. Ministerio de salud. Infestación por Aedes aegypti [Internet]. Lima; 2021. Disponible en: http://www.digesa.minsa.gob.pe/DCOVI/infestacion.pdf.

20. Bueno C, Vela F, Llontop A, Carranza J. Dengue en San Martín: Seis Años de Experiencias. Dirección Regional de Salud San Martín; 1998. 61 p.

Page 13/18 
21. Palomino M. Vigilancia de la resistencia a los insecticidas Enero - Junio 2019. Bol Inst Nac Salud. 2018;24(34):31-3.

22. Pinto J, Palomino M, Mendoza-Uribe L, Sinti C, Liebman KA, Lenhart A. Susceptibility to insecticides and resistance mechanisms in three populations of Aedes aegypti from Peru. Parasit Vectors. 2019;12(1):494.

23. Palomino M. Protocolo sanitario de urgencia para el reforzamiento de la vigilancia entomológica del vector Aedes aegypti mediante el uso de ovitrampas para establecimientos de salud: R.M. №10-2015/MINSA. Vol. 1. 2016.

24. Georghiou GP, Wirth M, Tran H, Saume F, Knudsen AB. Potential for organophosphate resistance in Aedes aegypti (Diptera: Culicidae) in the Carribean area and neighboring countries. J Med Entomol. 1987;24(3):290-4.

25. Reiter P, Amador MA, Colon N. Enhancement of the CDC ovitrap with hay infusions for daily monitoring of Aedes aegypti populations. J Am Mosq Control Assoc. 1991;7(1):52-5.

26. Consoli RAGB, Oliveira RL de. Principais mosquitos de importância sanitária no Brasil. Principais mosquitos de importância sanitária no Brasil. Rio de Janeiro: Editora FIOCRUZ; 1994.

27. Da-Cunha MP, Lima JBP, Brogdon WG, Moya GE, Valle D. Monitoring of resistance to the pyrethroid cypermethrin in Brazilian Aedes aegypti (Diptera Culicidae) populations collected between 2001 and 2003. Mem Inst Oswaldo Cruz. 2005;100(4):441-4.

28. World Health Organization. Monitoring and managing insecticide resistance in Aedes mosquito populations Interim guidance for entomologists. World Health Organization. Geneva; 2016.

29. Sá ELR de, Rodovalho CDM, Sousa NPR de, Sá ILR de, Bellinato DF, Dias LDS, et al. Evaluation of insecticide resistance in Aedes aegypti populations connected by roads and rivers: the case of Tocantins state in Brazil. Mem Inst Oswaldo Cruz. 2019;114:1-10.

30. Raymond M. Presentation d'une programme d'analyse logprobit pour microordinateur cahiers Orstrom. Sér Ent Med Parasitol. 1985;23(2):117-21.

31. Mazzarri MB, Georghiou GP. Characterization of resistance to organophosphate, carbamate, and pyrethroid insecticides in field populations of Aedes aegypti from Venezuela. J Am Mosq Control Assoc. 1995;11(3):315-22.

32. Bustios C, Rios A, Arroyo R, Marquez C, Miano J. La malaria y el dengue en la historia de la salud pública peruana 1821-2011. [Internet]. Lima; 2014. Disponible en: http://bvs.minsa.gob.pe/local/MINSA/3425.pdf.

33. Valle J. Reinfestación de la selva peruana por Aedes aegypti Linneo, 1762 (Diptera:Culicidae). Tesis de pregado. Universidad Ricardo Palma; 1989.

34. Neyra D, Cabezas C, Ruebush IIT. El proceso de adecuación y cambio en la política del tratamiento de la malaria por Plasmodium falciparum en el Perú, 1990-2001. Rev Peru Med Exp Salud Publica. 2003;20(3):162-71.

35. Organización Panamericana de la Salud. N8 Crónicas de desastres Fenómeno El Niño, 1997-1998. Washington: Organización Mundial de la Salud; 2000.

36. Organización Panamericana de la Salud. Documento operativo de aplicación del manejo integrado de vectores adaptado al contexto de las Américas. Documento operativo de aplicación del manejo integrado de vectores adaptado al contexto de las Américas. Washington, D.C.: OPS; 2019.

37. Organización Panamericana de la Salud. Abordaje de los determinantes ambientales de la salud en las estrategias de vigilancia y control de vectores: orientaciones para promover intervenciones clave. Washington, D.C.: OPS; 2019.

38. Valdez W, Ramos W, Miranda J, Tovar JC. Análisis de la situación de salud del Perú. Primera Ed. Lima: Ministerio de Salud; 2010.

39. Fernández WF, lannacone J. Variaciones de tres índices larvarios de Aedes aegypti (L.) (Diptera: Culicidae) y su relación con los casos de dengue en Yurimaguas, Perú, 2000 - 2002. Parasitol Latinoam. 2005;60:3-16. 
40. Barrantes R, Glave M. editores. Amazonía peruana y desarrollo económico. Primera Ed. Lima: Instituto de Estudios Peruanos (IEP), Grupo de Análisis para el Desarrollo. GRADE); 2014.

41. Ministerio de Salud. Aprendiendo de la experiencia. Lecciones aprendidas para la preparación y respuesta en el control vectorial ante brotes de dengue en el Perú. Dirección General de Salud Ambiental. Lima: Ministerio de Salud; 2011.

42. Dirección de Epidemiología. Análisis de situación de salud 2016. Madre de Dios: Dirección Regional de Salud Madre de Dios; 2016.

43. Salmón-Mulanovich G, Blazes DL, Guezala VMC, Rios Z, Espinoza A, Guevara C, et al. Individual and Spatial Risk of Dengue Virus Infection in Puerto Maldonado, Peru. Am J Trop Med Hyg. 2018;99(6):1440-50.

44. Chediak M, Pimenta G, Coelho F, Braga GE, Lima IA, Cavalcante JBP. KRLJ, et al. Spatial and temporal country-wide survey of temephos resistance in Brazilian populations of Aedes aegypti. Mem Inst Oswaldo Cruz. 2016;111(5):311-21.

45. López Rodríguez R. Estudio de la sensibilidad y/o resistencia a los insecticidas del Aedes aegypti, vector del dengue en Bolivia. Universidad de Barcelona; 2015.

46. Montoro Y, Moreno R, Gomero L, Reyes M. Características de uso de plaguicidas químicos y riesgos para la salud en agricultores de la Sierra Central del Perú. Rev Peru Med Exp Salud Publica. 2009;26(4):466-72.

47. Tupayachi Calderón ER. Transferencia de tecnología para el uso adecuado de plaguícidas agrícolas. Universidad Nacional Agraria La Molina; 2020.

48. Guerrero-Padilla AM, Otiniano-Medina LJ. Impacto en agroecosistemas generado por pesticidas en los sectores Vichanzao, El Moro, Santa Lucía de Moche y Mochica Alta, Valle de Santa Catalina, La Libertad. Perú Sciéndo. 2012;15(2):1-14.

49. Consejo Nacional del Ambiente. Dirección General de Salud Ambiental, Servicio Nacional de Sanidad Agraria. Plan nacional de implementación del convenio de Estocolmo sobre los contaminantes orgánicos persistentes en el Perú. 1st ed. Lima; 2007.

50. Thongwat D, Bunchu N. Susceptibility to temephos, permethrin and deltamethrin of Aedes aegypti (Diptera: Culicidae) from Muang district, Phitsanulok Province, Thailand. Asian Pac J Trop Med. 2015;14-8.

51. Wirth MC, Georghiou GP. Selection and characterization of temephos resistance in a population of Aedes aegypti from Tortola, British Virgin Islands. J Am Mosq Control Assoc. 1999;15(3):315-20.

52. Moyes CL, Vontas J, Martins AJ, Ng LC, Koou SY, Dusfour I, et al. Contemporary status of insecticide resistance in the major Aedes vectors of arboviruses infecting humans. PLoS Negl Trop Dis. 2017;11(7):e0005625.

53. Organización Panamericana de la Salud. Orientaciones para la estructuración de laboratorios de entomología en salud pública. Washington, D.C.: OPS; 2019.

54. Organización Mundial de la Salud. Directrices para el control de vectores del paludismo [Guidelines for malaria vector control]. Ginebra: Organización Mundial de la Salud. Licencia: CC BY-NC- SA 3.0 IGO.; 2019.

55. Muthusamy R, Shivakumar MS. Susceptibility status of Aedes aegypti (L.) (Diptera: Culicidae) to temephos from three districts of Tamil Nadu, India. J Vector Borne Dis. 2015;52:159-65.

56. Conde M, Orjuela LI, Castellanos CA, Herrera-Varela M, Licastro S, Quiñones ML. Evaluación de la sensibilidad en poblaciones de Aedes aegypti (Diptera: Culicidae) del departamento de Caldas, Colombia, en 2007 y 2011. Biomédica. 2015;35:43-52.

57. Araújo AP, Araujo Diniz DF, Helvecio E, de Barros RA, de Oliveira CMF, Ayres CFJ, et al. The susceptibility of Aedes aegypti populations displaying temephos resistance to Bacillus thuringiensis israelensis: a basis for management. Parasit Vectors. 2013;6:297. 
58. Marcombe S, Paris M, Paupy C, Bringuier C, Yebakima A, Chandre F, et al. Insecticide-driven patterns of genetic variation in the dengue vector Aedes aegypti in Martinique Island. PLoS One. 2013;8(10):e77857.

59. Andrighetti MTM, Cerone F, Rigueti M, Galvani KC, Da Graça Macoris ML. Effect of pyriproxyfen in Aedes aegypti populations with different levels of susceptibility to the organophosphate temephos. Dengue Bull. 2008;32:186-98.

60. Marcombe S, Fustec B, Cattel J, Chonephetsarath S, Thammavong P, Phommavanh N, et al. Distribution of insecticide resistance and mechanisms involved in the arbovirus vector Aedes aegypti in Laos and implication for vector control. PLoS Negl Trop Dis. 2019;13(12):e0007852.

61. Aguirre-Obando OA, Pietrobon AJ, Bona ACD, Navarro-Silva MA. Contrasting patterns of insecticide resistance and knockdown resistance (kdr) in Aedes aegypti populations from Jacarezinho (Brazil) after a Dengue Outbreak. Rev Bras Entomol. 2016;60:94-100.

62. Aguirre-Obando OA, Bona ACD, Duque L. JE, Navarro-Silva MA. Insecticide resistance and genetic variability in natural populations of Aedes (Stegomyia) aegypti (Diptera: Culicidae) from Colombia. Zoologia. 2015;32(1):14-22.

63. Tikar SN, Mendki MJ, Chandel K, Parashar BD, Prakash S. Susceptibility of immature stages of Aedes (Stegomyia) aegypti; vector of dengue and chikungunya to insecticides from India. Parasitol Res. 2008;102:907-13.

64. Macoris MDLDG, Andrighetti MTM, Otrera VCG, Carvalho LR de, Caldas Júnior AL, Brogdon WG. Association of insecticide use and alteration on Aedes aegypti susceptibility status. Mem Inst Oswaldo Cruz. 2007;102(8):895900.

65. Ishak IH, Jaal Z, Ranson H, Wondji CS. Contrasting patterns of insecticide resistance and knockdown resistance (kdr) in the dengue vectors Aedes aegypti and Aedes albopictus from Malaysia. Parasit Vectors. 2015;8:181.

66. Rocha HDR, Paiva MHS, Silva NM, de Araújo AP, Camacho D dos R da R de A, Moura AJF da, et al. Susceptibility profile of Aedes aegypti from Santiago Island, Cabo Verde, to insecticides. Acta Trop. 2015;152:66-73.

67. Ministerio de Salud. Boletin Epidemiologico Del Peru 2016 SE.52. 1st ed. Bueno C, Lizarbe M, Cruz A, editores. Lima: Ministerio de Salud; 2017.

68. Rawlins SC, Wan JO. Resistance in some Caribbean populations of Aedes aegypti to several insecticides. J Am Mosq Control Assoc. 1995;11(1):59-65.

69. Rawlins SC. Spatial distribution of insecticide resistance in Caribbean populations of Aedes aegypti and its significance. Rev Panam Salud Pública. 1998;4(4):243-51.

70. Lima EP, Paiva MHS, de Araújo AP, da Silva EVG, da Silva UM, de Oliveira LN, et al. Insecticide resistance in Aedes aegypti populations from Ceará, Brazil. Parasit Vectors. 2011;4:5.

71. Rahman RU, Cosme LV, Costa MM, Carrara L, Lima JBP, Martins AJ. Insecticide resistance and genetic structure of aedes aegypti populations from rio de Janeiro state, Brazil. PLoS Negl Trop Dis. 2021;15(2):1-25.

72. Rodríguez MM, Bisset JA, Fernández D. Levels of insecticide resistance and resistance mechanisms in Aedes aegypti from some Latin American countries. J Am Mosq Control Assoc. 2007;23(4):420-9.

\section{Figures}




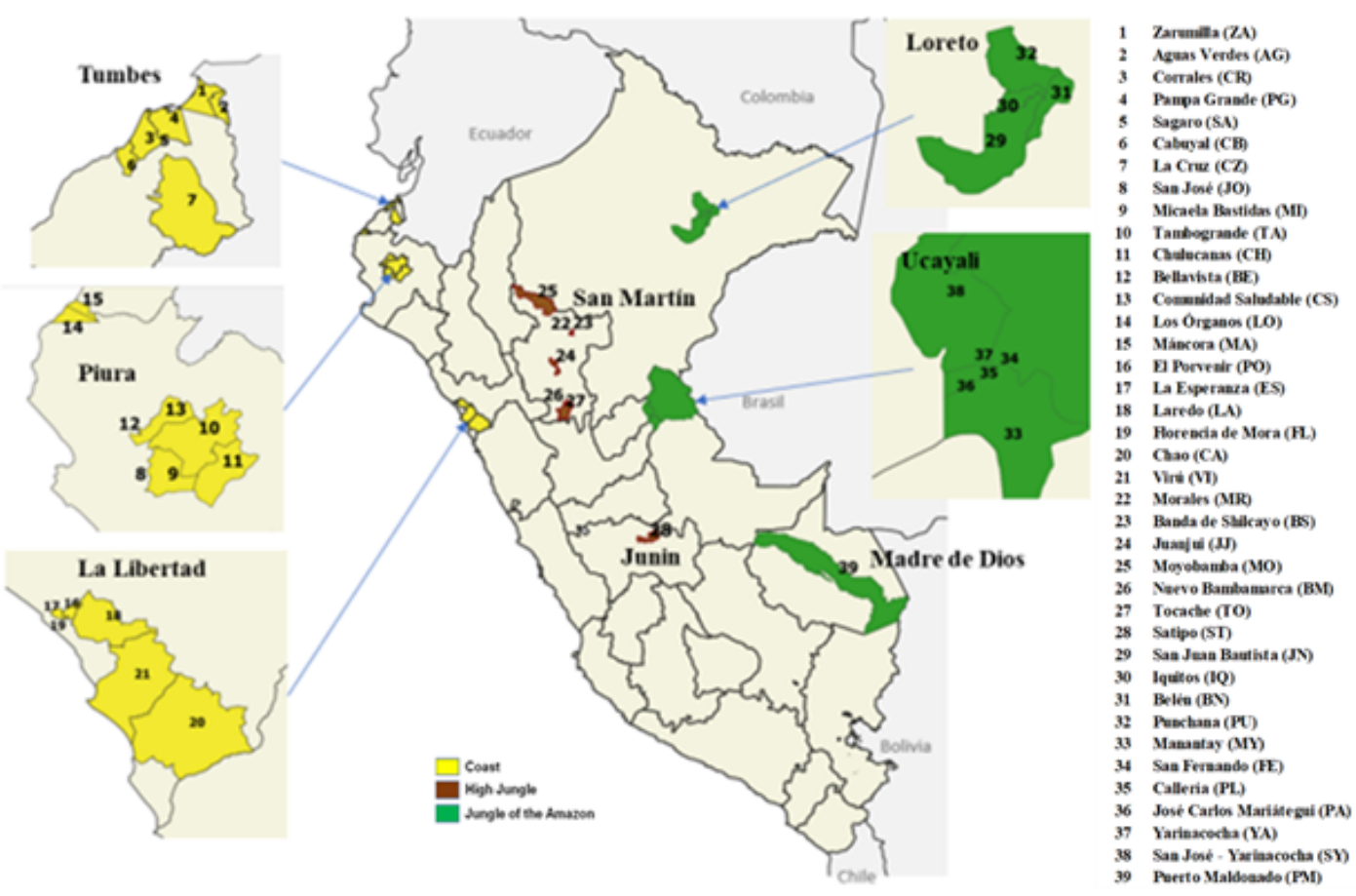

Figure 1

Map of the selected localities in the three ecological regions of Peru.

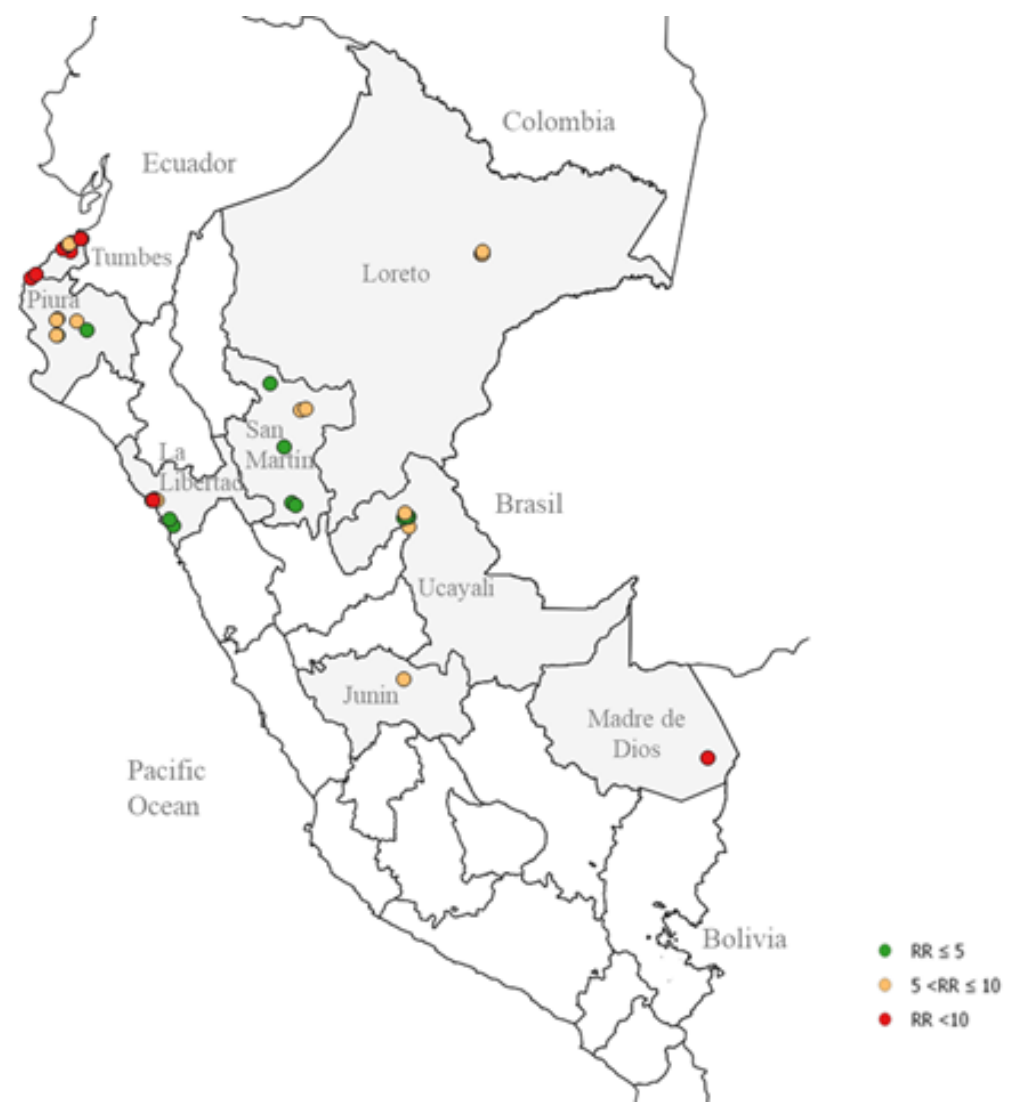

Figure 2

Temephos resistance ratios (RRs) in Peruvian populations of Ae. aegypti 2018-2019 

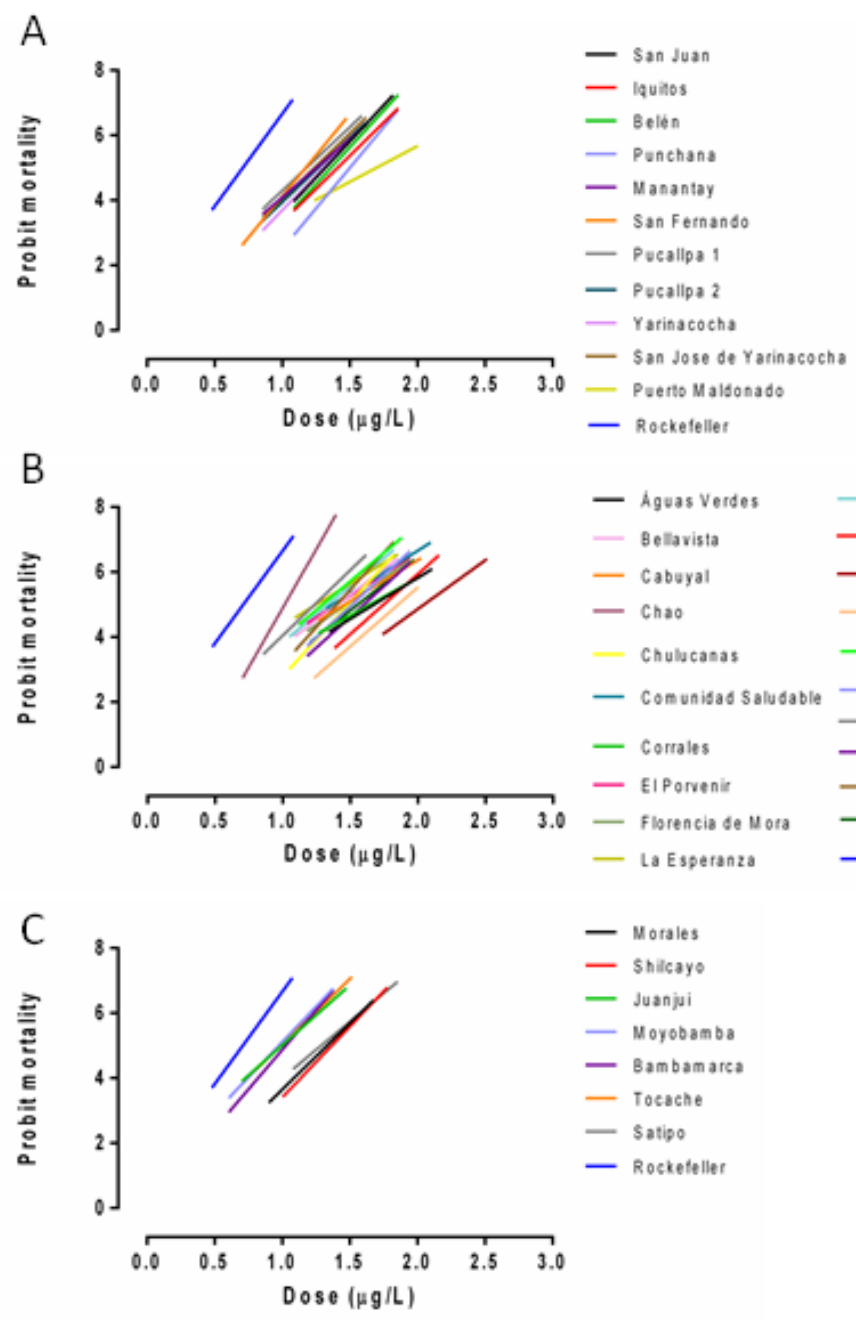

\section{Figure 3}

Linear regression of Aedes aegypti mortality after exposure to the organophosphate temephos in Peruvian populations compared to the susceptible Rockefeller strain (in blue). A: The jungle of the Amazon, B: Coast and C: High jungle. 